\title{
Monitoring of a fast-growing speleothem site from the Han-sur-Lesse cave, Belgium, indicates equilibrium deposition of the seasonal $\delta^{18} \mathrm{O}$ and $\delta^{13} \mathrm{C}$ signals in the calcite
}

\author{
M. Van Rampelbergh ${ }^{1}$, S. Verheyden ${ }^{1,2}$, M Allan $^{3}$, Y. Quinif ${ }^{4}$, E. Keppens ${ }^{1}$, and P. Claeys ${ }^{1}$ \\ ${ }^{1}$ Earth System Sciences, Vrije Universiteit Brussel (VUB), Pleinlaan, 1050, Brussels, Belgium \\ ${ }^{2}$ Royal Belgian Institute of Natural Sciences, Geological Survey, Direction Earth and History of Life, \\ Jennerstraat 13, 1000, Brussels, Belgium \\ ${ }^{3}$ AGEs, Départment de Géologie, Université de Liège, Allée du 6 Août, B18 Sart-Tilman, 4000, \\ Liège, Belgium \\ ${ }^{4}$ Faculté Polytechnique, Université de Mons, Rue de Houdain 9, 7000, Mons, Belgium \\ Correspondence to: M. Van Rampelbergh (mvrampel@vub.ac.be)
}

Received: 21 March 2014 - Published in Clim. Past Discuss.: 22 April 2014

Revised: 15 September 2014 - Accepted: 16 September 2014 - Published: 22 October 2014

\begin{abstract}
Speleothems provide paleoclimate information on multimillennial to decadal scales in the Holocene. However, seasonal or even monthly resolved records remain scarce. Such records require fast-growing stalagmites and a good understanding of the proxy system on very short timescales. The Proserpine stalagmite from the Han-sur-Less cave (Belgium) displays well-defined/clearly visible darker and lighter seasonal layers of 0.5 to $2 \mathrm{~mm}$ thickness per single layer, which allows a measuring resolution at a monthly scale. Through a regular cave monitoring, we acquired a good understanding of how $\delta^{18} \mathrm{O}$ and $\delta^{13} \mathrm{C}$ signals in modern calcite reflect climate variations on the seasonal scale. From December to June, outside temperatures are cold, inducing low cave air and water temperature, and bio-productivity in the soil is limited, leading to lower $p \mathrm{CO}_{2}$ and higher $\delta^{13} \mathrm{C}$ values of the $\mathrm{CO}_{2}$ in the cave air. From June to December, the measured factors display an opposite behavior.

The absence of epikarst water recharge between May and October increases prior calcite precipitation (PCP) in the vadose zone, causing drip water to display increasing $\mathrm{pH}$ and $\delta^{13} \mathrm{C}$ values over the summer months. Water recharge of the epikarst in winter diminishes the effect of PCP and as a result the $\mathrm{pH}$ and $\delta^{13} \mathrm{C}$ of the drip water gradually decrease. The $\delta^{18} \mathrm{O}$ and $\delta^{13} \mathrm{C}$ signals of fresh calcite precipitated on glass slabs also vary seasonally and are both reflecting equilibrium conditions. Lowest $\delta^{18} \mathrm{O}$ values occur during the summer,
\end{abstract}

when the $\delta^{13} \mathrm{C}$ values are high. The $\delta^{18} \mathrm{O}$ values of the calcite display seasonal variations due to changes in the cave air and water temperature. The $\delta^{13} \mathrm{C}$ values reflect the seasonal variation of the $\delta^{13} \mathrm{C}_{\mathrm{DIC}}$ of the drip water, which is affected by the intensity of PCP. This same anticorrelation of the $\delta^{18} \mathrm{O}$ versus the $\delta^{13} \mathrm{C}$ signals is seen in the monthly resolved speleothem record that covers the period between 1976 and 1985 AD. Dark layers display lower $\delta^{18} \mathrm{O}$ and higher $\delta^{13} \mathrm{C}$ values. The cave system varies seasonally in response to the activity of the vegetation cover and outside air temperature between a "summer mode" lasting from June to December and a "winter mode" from December to June. The low $\delta^{18} \mathrm{O}$ and high $\delta^{13} \mathrm{C}$ values of the darker speleothem layers indicate that they are formed during summer, while light layers are formed during winter. The darker the color of a layer, the more compact its calcite structure is, and the more negative its $\delta^{18} \mathrm{O}$ signal and the more positive its $\delta^{13} \mathrm{C}$ signal are. Darker layers deposited from summer drip water affected by PCP are suggested to contain lower $\mathrm{Ca}^{2+}$ concentration. If indeed the calcite saturation represents the main factor driving the Proserpine growth rate, the dark layers should grow slower than the white layers. 


\section{Introduction}

In the past 25 years, speleothem records have provided important information on past climate variations on multimillennial to decadal scales (e.g., Genty et al., 2003; McDermott, 2005; Verheyden et al., 2008b; Wang et al., 2008; Van Rampelbergh et al., 2013). With the increasing number of studies on cave calcite deposition dynamics (e.g., Dreybrodt, 1999, 2008; Verheyden et al., 2008a; Lachniet, 2009; Scholz et al., 2009; Ruan and Hu, 2010; Oster et al., 2012) and with the help of modern analytical tools (Fairchild et al., 2006; Spötl and Mattey, 2006; Jochum et al., 2012), progress has been made to measure resolution at sub-seasonal and even bi-monthly scales. However, only a few studies, so far, have reached such high temporal resolution for the measured proxies (Treble et al., 2003; Mattey et al., 2008) mainly due to following two limitations.

The first limitation to study the paleoclimate at the seasonal scale from stalagmites is that their growth rate needs to be significantly high (around $1 \mathrm{~mm} \mathrm{yr}^{-1}$ ) to deposit thick layers allowing monthly resolved time series. Speleothem growth rates vary according to different factors, such as drip water rate and calcium ion concentration (Baker et al., 1998; Dreybrodt, 1999), rendering the estimation of an average rate difficult. Generally, stalagmites increase at $10-100 \mu \mathrm{m} \mathrm{yr}^{-1}$ in cool temperate climates and at $300-500 \mu \mathrm{m} \mathrm{yr}^{-1}$ in subtropical climates (Fairchild et al., 2006), clearly showing that fast-growing (more than $1 \mathrm{~mm} \mathrm{yr}^{-1}$ ) speleothems are truly exceptional.

A second limitation is that a good understanding of the cave system is needed to understand what the measured proxies are reflecting. The interaction between the climate parameters, the soil, the host rock and the cave environment needs to be well understood for the studied cave and time frame. On classical multimillennial and centennial timescales, the processes influencing the stable isotopes of oxygen and carbon are well established (e.g., Fairchild et al., 2006; Baker et al., 2007). However, local cave-specific effects affect seasonally or even monthly resolved $\delta^{18} \mathrm{O}$ and $\delta^{13} \mathrm{C}$ signals. For studies at seasonal scales, a detailed study of the cave dynamics is required (Mattey et al., 2008) in order to understand which factors drive the isotopic signals, and at which intensity. In the last few years, different authors have tried to model how $\delta^{18} \mathrm{O}$ and $\delta^{13} \mathrm{C}$ signals are affected by temperature, drip rate, amount of $\mathrm{CO}_{2}$ degassing or residence time of the water film on the surface of the stalagmite (Mühlinghaus et al., 2007, 2009; Dreybrodt and Scholz, 2011; Deininger et al., 2012). Results of these studies have provided important progress in the understanding of the isotope system in cave environments. However, cave-monitoring programs remain of crucial importance to test in real cave environments the hypotheses derived from the models. Different cave-monitoring studies have been set up all over the world to better understand these seasonal and sub-seasonal processes (Genty and Deflandre, 1998; Spötl et al., 2005; Mattey et al., 2008;
Riechelmann et al., 2011). Only few of them have provided answers on the isotope fractionation processes occurring between the drip water and recent precipitated calcite due to the complexity of the system and the variety of the different specific environments (Verheyden et al., 2008a; Tremaine et al., 2011; Riechelmann et al., 2013).

Previous studies of the Han-sur-Lesse karst system show that the cave responds seasonally to external climate factors and that it is well suited for high-resolution speleothembased climate reconstructions (Genty and Quinif, 1996; Verheyden et al., 2006, 2008a). In the Han-sur-Lesse cave, the high growth rate (up to $2.1 \mathrm{~mm} \mathrm{yr}^{-1}$ ) and clear seasonal banding of the "Proserpine" stalagmite make it possible to reconstruct climate variations at the seasonal scale (Verheyden et al., 2006). In this study, we report results of a cave environment monitoring carried out once every 2 weeks for 1 year (2013) that shows how oxygen and carbon isotope signals obtained from the Proserpine banding reflect climate variations at the seasonal scale. The results are then compared to highresolution $\delta^{18} \mathrm{O}$ and $\delta^{13} \mathrm{C}$ signals measured on the 10 thickest layers from the upper $10 \mathrm{~cm}$ of the Proserpine, which cover the period from 1976 to 1985 AD. This approach improves the knowledge and accuracy for the use of $\delta^{18} \mathrm{O}$ and $\delta^{13} \mathrm{C}$ signals in speleothems at the seasonal scale.

\section{Study area and hydrological setting}

The Han-sur-Lesse cave is located within Givetian limestones of the Dinant synclinorium and is the largest and best-developed karst system in Belgium (Delvaux De Fenffe, 1985). The Lesse river formed the cave within a hill called the "Massif de Boine" entering the karst system at the "Gouffre de Belvaux" and exiting approximately $24 \mathrm{~h}$ later through the "Trou de Han" (Fig. 1). The cave has been exploited since the mid-19th century as a touristic attraction and is characterized by large chambers and well-developed speleothem formations. The cave monitoring and speleothem sampling for this study is carried out in the "Salle-Du-Dôme" chamber. This $150 \mathrm{~m}$ wide and $60 \mathrm{~m}$ high chamber formed by collapse and is the largest of the whole cave system. The Proserpine stalagmite is easily reachable following the tourist path into the cave for approximately $700 \mathrm{~m}$ from the cave's exit at the Trou de Han (Fig. 1). It has a large tabular shape with a relatively horizontal slightly undulating surface of about $1.5 \mathrm{~m}^{2}$ and is fed by a continuous high drip water flow that drips on mainly four sites. The epikarst thickness above the cave chamber is estimated to be $40 \mathrm{~m}$ (Quinif, 1988). Two passages connect the Salle-Du-Dôme to the neighboring chambers, and the Lesse river flows at the bottom of the chamber.

The mean annual precipitation at the nearest meteorological station of Han-sur-Lesse is $844 \mathrm{~mm} \mathrm{yr}^{-1}$, and the mean annual air temperature is $10.3^{\circ} \mathrm{C}$ (Royal Meteorological Institute Belgium). While the temperature displays a wellmarked seasonality with cool summers and mild winters, the 

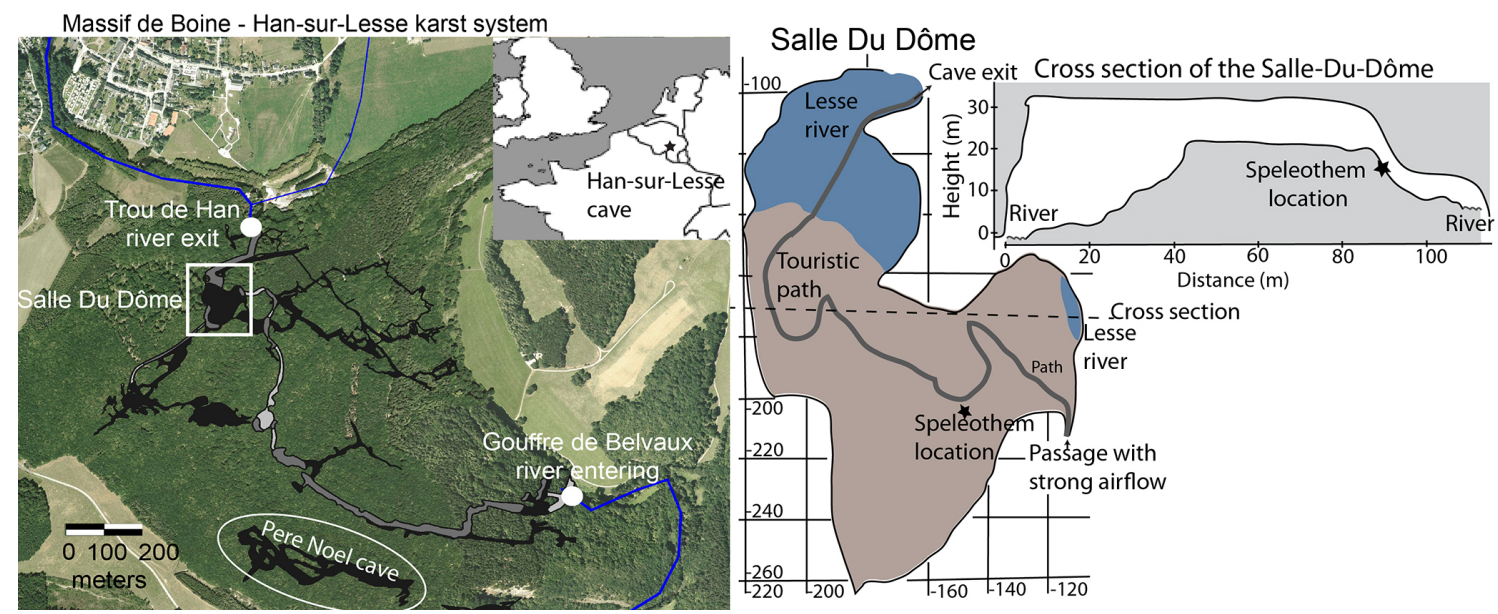

Figure 1. The Han-sur-Lesse karst system, with the Han-sur-Lesse cave as the northern cave system and the Père Noël cave (Verheyden et al., 2008a) as the southern cave system. The Lesse river enters the cave system at the "Gouffre de Belvaux" and exits $24 \mathrm{~h}$ later at the "Trou de Han". The studied speleothem is located in the "Salle-du-Dôme" and grows on a pile of debris. Figure adapted after Quinif (1988).

rainfall is spread all over the entire year. According to the Köppen and Geiger classification, the climate above the Hansur-Lesse cave is considered as a warm temperate, fully humid climate with cool summers (Kottek et al., 2006). For the studied period lasting between November 2012 and January 2014, air temperature was at its lowest between December and March and highest between July and September. The coldest temperature of $-4.2^{\circ} \mathrm{C}$ was reached on 15 March 2013. Such an unusually cold March is an exception and does not represent the average weather conditions for the studied region. The plant coverage above the cave consists of C3type vegetation with oaks, beech and hazel trees. The soil is approximately $40 \mathrm{~cm}$ tick and consists of silty stony soil with more than $50 \%$ limestone fragments (Belgian Geological Survey map). The area above the cave is part of a protected natural reserve, preserved from direct human influence for more than 50 years.

\section{Methods}

Between October 2012 and January 2014, the cave was visited every 2 weeks to record environmental parameters. To make sure that the measured parameters are closely reflecting the natural conditions and to guarantee a consistent measurement campaign, the cave parameters were always measured around 09:00 a.m. before the first visitor enters the cave. To investigate the visitors' possible influence on the measured cave parameters, a test was carried out by measuring these parameters before visitors were allowed into the cave and after the passage of different groups. Cave air and water temperature were measured with a HANNA HI955501 thermometer with a precision of $0.2{ }^{\circ} \mathrm{C}$. Air temperature was taken directly above the stalagmite. The drip water temperature and $\mathrm{pH}$ were determined in a small natural pool $(6 \mathrm{~cm}$ wide and $3 \mathrm{~cm}$ deep) formed on the stalagmite's surface, where drip water is continuously falling in. The extremely short residence time of the water in this small pool guarantees that the temperature and $\mathrm{pH}$ suffer minimal alteration. The $\mathrm{pH}$ of the drip water was measured with a HANNA HI991300 sensor (precision of $0.01 \mathrm{pH}$ ). The concentration of $\mathrm{CO}_{2}$ in the cave air was obtained using an ACCURO 640000 manual Dräger pump with a standard deviation of 10 to $15 \%$. Three times per visit, $p \mathrm{CO}_{2}$ values were measured at the same spot, right above the surface of the speleothem, and reported as an average of the three values. The drip water discharge (volumetric flow rate, here given in volume $(\mathrm{mL})$ of water reaching the speleothem surface per minute) above the Proserpine stalagmite was measured in a graded cylinder after collecting the drip water during $10 \mathrm{~min}$ in an inflatable soft plastic swimming pool $\left(1.77 \mathrm{~m}^{2}\right)$ which was placed on the stalagmite's surface to collect the drips from the four drip sites of the Proserpine. Drip water samples for $\delta^{18} \mathrm{O}$ and $\delta \mathrm{D}$ measurements were collected using a container placed at the surface of the stalagmite, where the drip fell from the stalactite approximately $30 \mathrm{~m}$ above the stalagmite. Water samples were stored in fully filled glass bottles in a cool and dark environment. Rainwater samples for $\delta^{18} \mathrm{O}$ and $\delta \mathrm{D}$ measurements were collected in a garden close to the cave using a thermos bottle and sampled every 15 days between November 2012 and January 2014. To avoid evaporation processes, the rainwater was collected using a funnel with a raised edge and connected to a tube reaching the bottom of the thermos bottle. The funnel was attached to the bottle through a hermetic cap. Glass bottles were fully filled with the collected rainwater and stored in a dark fridge until being analyzed.

The $\delta^{18} \mathrm{O}$ and $\delta \mathrm{D}$ composition of the waters were measured using a PICARRO L2130-i Cavity Ring-Down Spectrometer at the Vrije Universiteit Brussel (VUB). For every 
sample $1.4 \mathrm{~mL}$ of water was used for the measurements. Every sample was injected and analyzed 10 consecutive times. The measured values were then corrected using house standards with a strongly different isotopic composition. The first house standard, called DO1, has a $\delta^{18} \mathrm{O}$ value of $-0.79 \pm 0.04 \%$ and a $\delta \mathrm{D}$ value of $-26.2 \pm 0.2 \%$ and was made by collecting the damp of boiling water. The second house standard, called DO2, is Milli-Q water with a $\delta^{18} \mathrm{O}$ composition of $-7.38 \pm 0.04 \%$ and a $\delta \mathrm{D}$ value of $-48.8 \pm 0.2 \%$. The third house standard, called DO3, is water from Antarctic glacier ice that was filtered and has a $\delta^{18} \mathrm{O}$ composition of $-14.77 \pm 0.04 \%$ and a $\delta \mathrm{D}$ composition of $-105.1 \pm 0.2 \%$. The most positive (DO1) and the most negative (DO3) house standards are used to obtain a two-point calibration line. The DO2 house standard, with intermediate values, serves as a "target" or "control" point. By using these three standards, we can correct the measured values for a lateral difference as well as for a stretch that can occur in the measurement range. All three working standards were made in the lab and calibrated against the international standards VSMOW2 (Vienna Standard Mean Ocean Water 2), GISP (Greenland Ice Sheet Precipitation) and SLAP2 (Standard Light Antarctic Precipitation 2). These three international standards were used to correct the house standards in the same way the DO1, DO2 and DO3 standards are used to correct the measurements. The calibration curve was obtained using VSMOW2 and SLAP2, and the GISP standard was used as target. Every house standard was measured 55 times on the PICARRO L2130-i. The collected rain and drip water samples were analyzed two times in different order. The reported values are the average of the two measurements and reported in per mill VSMOW. Analytical uncertainties $(2 \sigma)$ equal $0.07 \%$ or the measured $\delta^{18} \mathrm{O}$ values and $0.5 \%$ 。 for the measured $\delta \mathrm{D}$ values.

The isotopic composition of the cave air $\mathrm{CO}_{2}$ was measured from samples collected by filling vacuum $2 \mathrm{~L}$ glass containers. To avoid "human" contamination, these samples were taken at the beginning of every cave visit. The $\mathrm{CO}_{2}$ was extracted from the container using a manual extraction line at the VUB. The extracted $\mathrm{CO}_{2}$ was then analyzed for its isotopic composition on a Thermo Delta plus XL mass spectrometer in dual-inlet mode. The standard deviation of the three measurements reports the error on the measured $\delta^{13} \mathrm{C}$ value. The $2 \sigma$ values average $0.6 \%$. All values are reported in per mill VPDB (Vienna Pee Dee Belemnite).

Samples for the analyses of the $\delta^{13} \mathrm{C}$ composition of the dissolved inorganic carbon (DIC) in the water were collected by filling $12 \mathrm{~mL}$ gastight glass tubes all the way to the top to avoid air $\mathrm{CO}_{2}$ contamination. A drop of $\mathrm{HgCl}_{2}$ was immediately added and the bottle hermetically closed and stored in a dark and cool environment until being analyzed. The day before the analysis, a headspace was created in the bottle by taking out $3 \mathrm{~mL}$ of water, while bubbling He through the septum. Once the headspace was formed, $\mathrm{H}_{3} \mathrm{PO}_{4}$ was added and the sample shaken overnight to convert all DIC species into
$\mathrm{CO}_{2}$. The $\mathrm{CO}_{2}$ gas was then extracted from the bottle and measured for its $\delta^{13} \mathrm{C}$ composition. Samples were duplicated and measured immediately after sampling and 1 month later to test whether degassing processes affect the DIC composition. This sampling and storing method was tested against the method described by Spötl et al. (2005) and delivers similar results within the analytical uncertainties. The $\delta^{13} \mathrm{C}$ composition of the DIC was measured on a Flash EA 1112 device connected to a Delta $\mathrm{V}$ plus mass spectrometer. The injected $\mathrm{CO}_{2}$ is measured against a house standard that consists of $\mathrm{CO}_{2}$ gas with a $\delta^{13} \mathrm{C}$ composition of $-34.07 \%$. The measurement series starts with five house standard injections. After a series of five samples a new house standard injection is measured to correct the drift. The house standard is calibrated against two international standards, IAEA-CH6 (sucrose) and IAEA-CH7 (polyethylene). All measurements are reported in per mill VPDB with an analytical uncertainty of $0.4 \% o(2 \sigma)$.

During every visit, three glass slabs were placed on the surface of the stalagmite to study current calcite deposition conditions on the surface of the stalagmite. All three slabs were positioned very near to where the speleothem core was drilled and collected during the next visit. Each time, all three collected slabs were always completely covered with calcite. The freshly precipitated calcite was then scraped off from the entire slab. Five aliquots per slab were taken from the collected powder and measured for their $\delta^{18} \mathrm{O}$ and $\delta^{13} \mathrm{C}$ composition. The reported value per cave visit is the average of the results of all 15 aliquots of the three slabs collected during each visit.

In January 2011, the Proserpine was sampled by drilling a $1 \mathrm{~m}$ long core in the middle of the large stalagmite. A slab was cut from the middle of the core and polished with $\mathrm{Al}_{2} \mathrm{O}_{3}$ powder. Layer counting established the age model of the upper $16 \mathrm{~mm}$ of the core, knowing that one dark and one light layer are deposited every year (Verheyden et al., 2006). Layer counting was carried out on high-resolution scans using Adobe Photoshop, by counting on the slab itself and by using the Merchantek MicroMill microscope. Samples to test the evolution of the isotopic composition of the individual layers were milled in nine consecutive layer couplets, where the dark and white layers were the largest. Samples were drilled every $40 \mu \mathrm{m}$ over a length of $4 \mathrm{~mm}$ with a Merchantek MicroMill, giving a temporal resolution of approximately 1 sample a month. The glass slab and speleothem calcite powders were measured for their $\delta^{18} \mathrm{O}$ and $\delta^{13} \mathrm{C}$ composition using a Kiel III device coupled on a Thermo Delta plus XL. All values were corrected using the international calcite powder standard NBS-19 and reported in per mill VPDB. Analytical uncertainties $(2 \sigma)$ were $\leq 0.12 \%$ or $\delta^{13} \mathrm{C}$ and $\leq 0.16 \%$ or $\delta^{18} \mathrm{O}$. 


\section{Results}

The drip water feeding the Proserpine falls from a small drapery-shaped stalactite, indicating that only a small part of the dissolved calcite precipitates from the drip water when hanging on the ceiling of the cave. The drip falls approximately $30 \mathrm{~m}$ before reaching the surface of the Proserpine. The Proserpine grows under a "flow" or continuous "rain" that falls on the surface of the stalagmite at four points. The core used in this study was sampled in the center of the speleothem, where water flows on the stalagmite during the whole year.

Figure 2 presents the results of the cave-monitoring campaign from November 2012 to January 2014 (15 months) together with precipitation amounts and air temperatures at the RMI station of Han-sur-Lesse (Fig. 2a and b, respectively) for the same period. No difference in the measured cave parameters is observed before the start of the visits and after a large number of visitors entered the chamber. The cave air temperature (Fig. 2c) in the Salle-Du-Dôme varies seasonally over a range of ca. $4{ }^{\circ} \mathrm{C}$, with highest values reaching up to $14.5^{\circ} \mathrm{C}$ in August and lowest value of $10.5^{\circ} \mathrm{C}$ in February. After the warm month of August, temperature values decrease gradually until December. From December through the end of May, temperatures remain stable and vary around an average of $11^{\circ} \mathrm{C}$. In July, the temperature increases quickly to reach the warmest values in August.Drip water temperatures (Fig. 2d) follow a similar trend as the cave air temperature (Fig. 2c) but are on average $0.5^{\circ} \mathrm{C}$ colder.

The drip flow of the Proserpine was always measured for the whole stalagmite, thus including the four drip sites, to have an idea of how much water is dripping on the whole surface of the speleothem. The water flow above the Proserpine stalagmite (Fig. 2e) averages $161 \mathrm{~mL} \mathrm{~min}^{-1}$. It sharply increases during early winter (December) to an average value above $200 \mathrm{~mL} \mathrm{~min}^{-1}$ to remain high throughout winter and spring until early summer (June), when it decreases again to around $100 \mathrm{~mL} \mathrm{~min}^{-1}$. With a discharge of $3 \times 10^{-3} \mathrm{~L} \mathrm{~s}^{-1}$ and a coefficient of variation of approximately 2 , the drip site can be characterized as a "percolation stream" according to the classification of Smart and Friederich (1987). In early June, discharge record shows a short maximum to $280 \mathrm{~mL} \mathrm{~min}^{-1}$, which is most probably related to the heavyrainfall period at the end of May 2013 (Fig. 2a). Superimposed on this seasonal cycle, very short events of increased drip flow are observed within $24 \mathrm{~h}$ following a heavy-rainfall event.

The drip water pH (Fig. 2f) varies between 8.4 and 7.9, decreasing in spring (sharply in May) and gradually increasing back at the end of summer and throughout autumn (from September through January). The heavy-rainfall period at the end of May 2013 (Fig. 2a) seems to correspond with a pH decrease below 8.0. The $p \mathrm{CO}_{2}$ values (Fig. $2 \mathrm{~g}$ ) remain relatively stable around $500 \mathrm{ppm}$ throughout much of the year ex- cept for a marked increase in the summer, reaching $1000 \mathrm{ppm}$ in July and August. The $\delta^{13} \mathrm{C}$ signature (Fig. 2h) of the cave air varies around an average of $-19.5 \%$, displaying an anticorrelation to that of the $p \mathrm{CO}_{2}$ concentrations. The $\delta^{13} \mathrm{C}$ of the DIC (Fig. 2i) varies between $-12.2 \pm 0.3 \%$ and $-11.0 \pm 0.3 \%$, increases between June and November and decreases between December and May.

Rainwater $\delta^{18} \mathrm{O}$ values (Fig. 3c) average $-8.18 \pm 0.07 \%$, and the $\delta \mathrm{D}$ values (Fig. $3 \mathrm{~d}$ ) $-55.52 \pm 0.5 \%$. The $\delta^{18} \mathrm{O}$ and $\delta \mathrm{D}$ signals increase by $3 \%$ and $30 \%$, respectively, during the summer months, presumably due to temperature effect. One larger drop (red arrow in Fig. 3c and d) of 9\%o for the $\delta^{18} \mathrm{O}$ and of $90 \%$ for the $\delta \mathrm{D}$ signal occurs at the beginning of March.

The drip water $\delta^{18} \mathrm{O}$ and $\delta \mathrm{D}$ values (Fig. $3 \mathrm{e}$ and $\mathrm{f}$ ) weakly vary around an average of $-7.65 \pm 0.07 \%$ and $-50.1 \pm 0.5 \%$, respectively. These values appear slightly higher compared to the yearly average $\delta^{18} \mathrm{O}$ and $\delta \mathrm{D}$ values of the rainwater. The drip water isotopic records of oxygen and hydrogen are well correlated and remain stable throughout the year with the exception of one small but meaningful negative excursion in July and August of $0.06 \%$ for $\delta^{18} \mathrm{O}$ and of $0.5 \%$ for $\delta \mathrm{D}$ (red arrow in Fig. 3e and f). The range of these shifts is on the order of the analytical uncertainties $\left(0.07 \%\right.$ o for $\delta^{18} \mathrm{O}$ and $0.5 \%$ ofor $\left.\delta \mathrm{D}\right)$, but they are recorded by at least four consecutive measurements, suggesting that they are significant.

The $\delta^{18} \mathrm{O}$ signal of the calcite recovered from glass slabs placed on top of the stalagmite (Fig. 2l) remains stable at $-6.5 \pm 0.16 \%$ most of the year but decreases to more negative values of $-7.1 \pm 0.16 \%$ o during summer (JJA) (red arrow in Fig. 21). The slabs' calcite $\delta^{13} \mathrm{C}$ signal (Fig. 2m) remains relatively constant at $-10 \pm 0.12 \%$ oxcept for a bulge from August through January, with maximal $\delta^{13} \mathrm{C}$ values of $-9.0 \pm 0.12 \%$ at the end of October (blue arrow in Fig. $2 \mathrm{~m}$ ). The two isotopic signatures are decoupled, suggesting that different forcing factors affect these signals.

The individual layers of the Proserpine stalagmite also display an anticorrelation pattern between the oxygen and carbon isotopic signals. The $\delta^{18} \mathrm{O}$ composition oscillates around an average $-6.5 \pm 0.16 \%$ over a range of $0.9 \%$. The $\delta^{13} \mathrm{C}$ varies around an average $-8.4 \pm 0.12 \%$ and over a range of $2.4 \%$. Both oxygen and carbon isotopic signals measured in the stalagmite correspond to the values measured on the glass slabs. At the end of a dark layer (dotted lines in Fig. 4) $\delta^{18} \mathrm{O}$ values reach their minimum while the $\delta^{13} \mathrm{C}$ values reach their maximum, illustrating the anticorrelation pattern between the $\delta^{18} \mathrm{O}$ and $\delta^{13} \mathrm{C}$ values at seasonal level. 


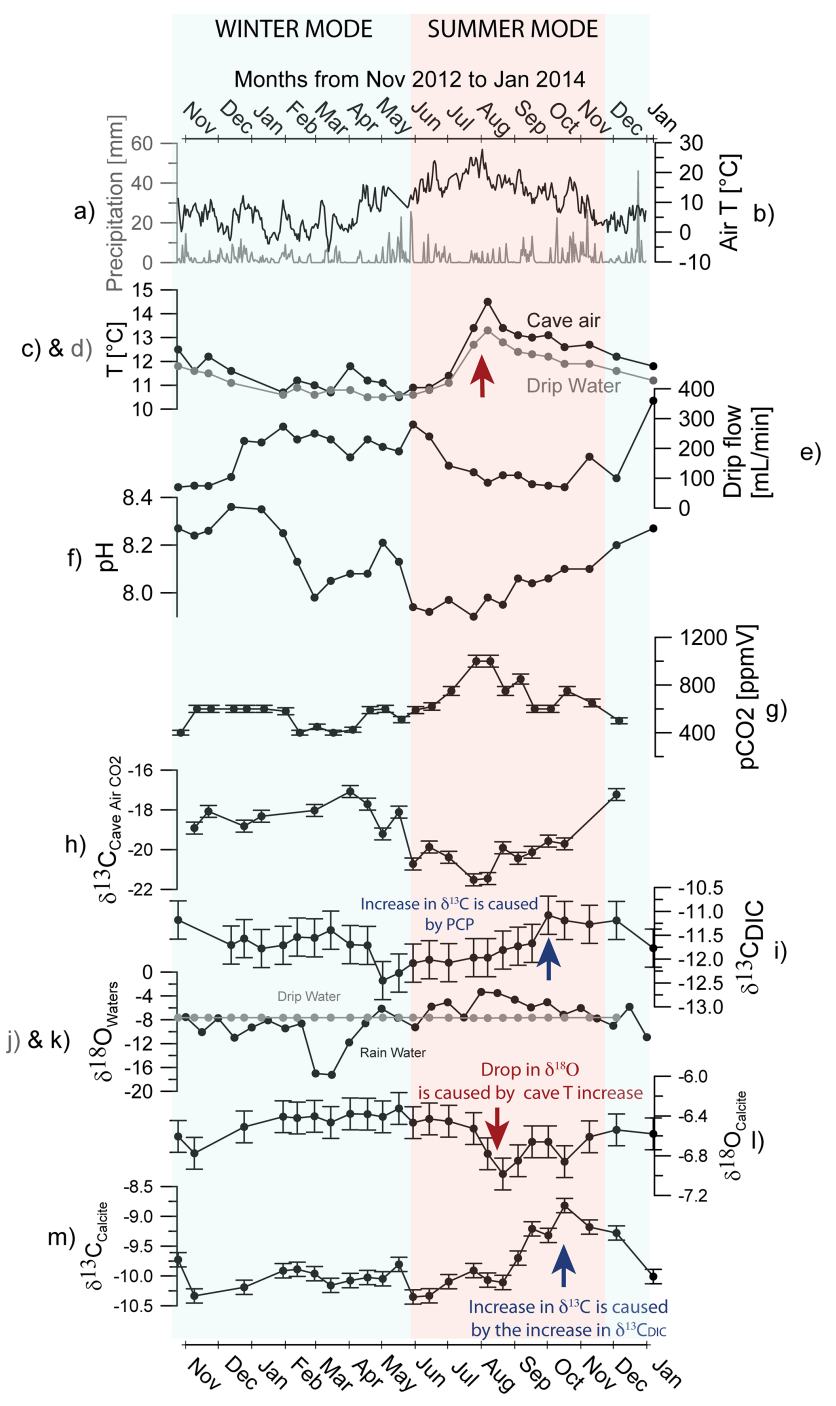

Figure 2. Precipitation intensities (a) and air temperatures (b) are measured at the Han-sur-Lesse station of the Royal Meteorological Institute. All measured cave parameters - the cave air and drip water temperature (c and d), drip flow (e), drip water $\mathrm{pH}$ (f), cave air $p \mathrm{CO}_{2}(\mathbf{g}), \delta^{13} \mathrm{C}_{\text {CAVE AIR CO2 }}(\mathbf{h}), \delta^{13} \mathrm{C}_{\text {DIC }}$ (i), $\delta{ }^{18} \mathrm{O}_{\mathrm{RAINWATER}}$ (j), $\delta^{18} \mathrm{O}_{\text {DRIP WATER }}(\mathbf{k})$, and the $\delta^{18} \mathrm{O}(\mathbf{l})$ and $\delta^{13} \mathrm{C}(\mathbf{m})$ of freshly deposited calcite on glass slabs - were measured during the cavemonitoring campaign from November 2012 through January 2014. Cave-monitoring results show that the cave conditions vary seasonally between a "summer mode" (red shadow) lasting from June to December and a "winter mode" (blue shadow) lasting from December to June. The water $\delta^{18} \mathrm{O}$ values ( $\mathbf{j}$ and $\mathbf{k}$ ) are reported in per mill VSMOW. $\delta^{13} \mathrm{C}_{\text {CAVE AIR CO2 }}(\mathbf{h}), \delta^{13} \mathrm{C}_{\text {DIC }}(\mathbf{i})$, and $\delta^{13} \mathrm{C}$ and $\delta^{18} \mathrm{O}$ of freshly deposited calcite on the glass slabs (l and $\mathbf{m})$ are reported in per mill VPDB.

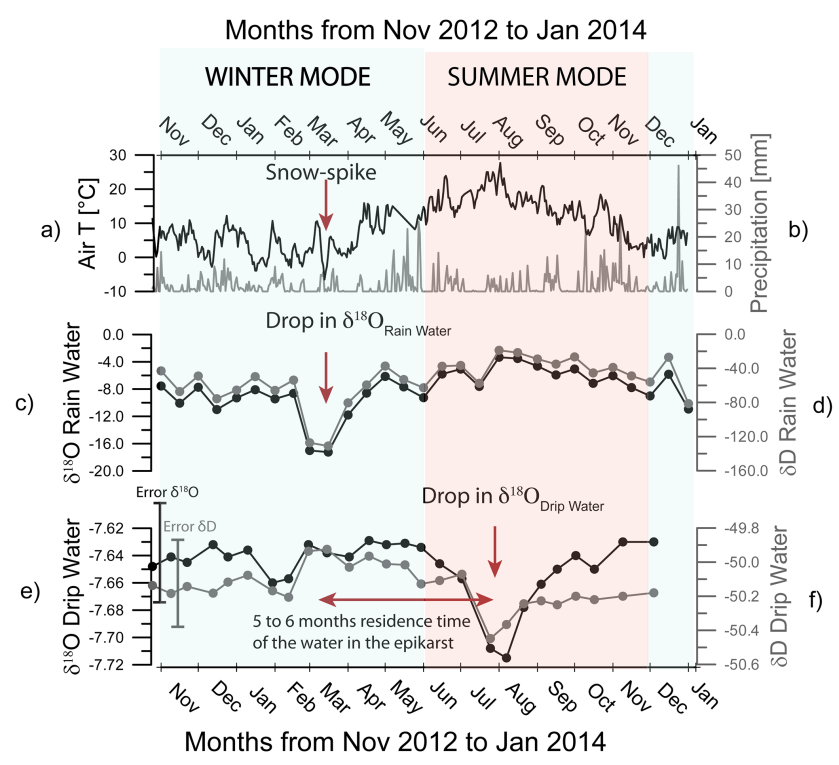

Figure 3. Precipitation (a) and air temperatures (b) are measured at the Han-sur-Lesse station of the Royal Meteorological Institute. The $\delta^{18} \mathrm{O}$ and $\delta \mathrm{D}$ of the rainwater (c and $\left.\mathbf{d}\right)$ and the $\delta^{18} \mathrm{O}$ and $\delta \mathrm{D}$ of the drip water (e and $\mathbf{f}$ ) are all reported in per mill VSMOW. At the end of March a cold temperature peak and prolonged snowfall cause the rainwater $\delta^{18} \mathrm{O}$ to display a sharp drop. This negative spike in the ${ }^{18} \mathrm{O}_{\text {rain water }}$ in March can be found back in the ${ }^{18} \mathrm{O}_{\text {drip water }}$ in August, indicating that at least part of the infiltrating water reaches the cave 5 to 6 months later.

\section{Discussion}

\subsection{Forcing of the rain and drip water $\delta^{18} \mathrm{O}$ and $\delta$ D variations}

Generally, rainwater $\delta^{18} \mathrm{O}$ values at a specific location vary due to temperature changes, variation in the amount of rainfall, fluctuations in the source of the rainwater or cloud track (Rozanski et al., 1992). The rainwater $\delta^{18} \mathrm{O}$ signal increases by a few per mill during the summer months, when air temperature is higher (Fig. 3a and c). A single larger drop in drip water $\delta^{18} \mathrm{O}$ of about $0.1 \%$ occurs in March 2013 and is indicated by a red arrow in Fig. 3. Although it is only of the size of the analytical uncertainty, we consider it meaningful because several points support it and it is the only excursion of this magnitude. This larger drop does not correspond with a decrease in temperature or with an increase in rainfall amount. A modification in rainwater source could be a plausible explanation but is not supported by changes in wind direction during that month based on RMI data. On the other hand, in March 2013 an unusually late snow layer covered the area for several weeks (RMI data). The observed decrease in $\delta^{18} \mathrm{O}$ is then most probably related to the collection of isotopically light snow in the sampling bottle.

The average $\delta^{18} \mathrm{O}$ and $\delta \mathrm{D}$ compositions of the drip water are slightly higher compared to the average $\delta^{18} \mathrm{O}$ and $\delta \mathrm{D}$ 
compositions of the rainwater. This slight increase in $\delta$ values is possibly due to evaporation of precipitated meteoric water from the surface before percolating into the epikarst, leading to slightly increased $\delta^{18} \mathrm{O}$ and $\delta \mathrm{D}$ values in the vadose water and in the drip water. Effective precipitation calculations using the Thornthwaite (1948) equation on the Han-sur-Less RMI data set for the years of 2011 and 2012 indicate that January is the only month where no evapotranspiration affects the isotopic composition of the water (Bonniver, 2011). Higher evaporation of a part of the precipitating water during the summer half year is most probably responsible for the slightly more positive $\delta^{18} \mathrm{O}$ and $\delta \mathrm{D}$ values in the drip water compared to the average rainwater $\delta^{18} \mathrm{O}$ and $\delta \mathrm{D}$ values.

The $\delta^{18} \mathrm{O}$ and $\delta \mathrm{D}$ compositions of the drip water display almost no variations throughout the year, indicating that the water residence time is sufficiently long to homogenize its isotopic composition (Fig. 2j). No detailed hydrological study of the Han-sur-Lesse cave system was carried out during this study. However, the water residence time in the epikarst is supposed to be on the order of months to years. In general, depending on the epikarst thickness and epikarst flow systems, the transfer time of the drip water from the surface, via the soil and epikarst, to the cave can vary from months to several decades. The epikarst thickness above the Han-sut-Lesse cave ( $40 \mathrm{~m})$ is similar to that observed in shallow caves such as Ernesto Cave in Italy or Bunker Cave in Germany with epikarst thicknesses between 15 and $30 \mathrm{~m}$. Drip water residence times in such caves are suggested to vary from months to years (Kluge et al., 2010; Miorandi et al., 2010). Considering similar flow patterns, the Han-surLesse residence time of the water in the epikarst may also be on the order of months to years such as Ernesto and Bunker caves rather than on the order of decades such as observed in deep caves such as Monte Corchia ( $-1187 \mathrm{~m}$ ) (Piccini et al., 2008).

The Proserpine drip water $\delta^{18} \mathrm{O}$ displays a small negative excursion of $0.1 \%$ in July and August (Fig. 3e). This small drop in the drip water composition is most probably related to the strong decrease in isotopic composition of the rainwater in March due to a single brief last snowfall. However, the intense mixing of the percolating vadose water in the epikarst reduces the $\delta^{18} \mathrm{O}$ shift of about $8 \%$ in the meteoric to a hardly detectable one of about $0.1 \%$ in the drip water. The presence of this $\delta^{18} \mathrm{O}$ minimum suggests that possibly a small part of the infiltrating water reaches the cave within 5 to 6 months, albeit strongly mixed with the larger epikarst reservoir. A similar functioning was suggested in the Père Noël cave, which also forms part of the Han-sur-Lesse karst system (Verheyden et al., 2008a). Uranine-tracing tests of the Père Noël epikarst showed first tracer occurrence $200 \mathrm{~h}$ after injection, with long restitution time of the curve going up to $>600 \mathrm{~h}$ containing superimposed smaller uranine concentration peaks (Bonniver, 2011). They described the epikarst as a large reservoir where a part of the infiltrating water has a fast flow to the cave while another part is stored for longer time spans. A similar situation may be present in the epikarst above the Proserpine. However, a more detailed understanding of the epikarst system with additional tracer tests is needed. So far, the hydrological system above the Proserpine is interpreted as a piston flow system with the first waters coming through after half a year.

\subsection{Seasonal variations of the cave atmosphere and drip flow}

A large number of visitors enter the cave and the Salle-duDôme chamber every day. Such a large number of visitors can induce an artificial increase in temperature, $p \mathrm{CO}_{2}$ levels or a decrease in humidity (Baker and Genty, 1998). The studied Salle-du-Dôme chamber has a height of $60 \mathrm{~m}$ and a width of $150 \mathrm{~m}$, for a total volume of $124000 \mathrm{~m}^{3}$, and a river flowing at the bottom of the chamber causing good air mixing. Due to the large size and the good ventilation of the chamber, the effect of the visitors on the measured parameters is expected to be negligible. This was confirmed by a series of tests where similar cave parameter values were measured before and after groups visited the chamber. For the Salle-duDôme chamber, we consider the measured values to reflect the natural conditions of the cave atmosphere. No cave entrances connected to the studied Salle-du-Dôme have been artificially enlarged.

Based on our observations, the temperatures of cave air, drip water and outside air all follow the same seasonal cycle. However, the air temperature, which varies between $20^{\circ} \mathrm{C}$ in summer and $0{ }^{\circ} \mathrm{C}$ in winter outside the cave, only varies between $14^{\circ} \mathrm{C}$ and $11^{\circ} \mathrm{C}$ inside the cave, respectively. Apart from the influence of the external temperature, the temperature regulation of the Salle-du-Dôme chamber is probably also influenced by the Lesse river flowing at the bottom of the chamber. Due to the water flow, a good mixing of the cave air is induced, causing the outside air to enter the cave chamber more easily. In addition, the water of the river transports energy from the outside (gained before it entered the cave) to the inner cave. This heat can then be released in the cave with more impact in the warm summer months than in the winter months. Since no temperature record of the river is available, the effect of the Lesse river on the cave air temperature cannot be quantified.

Compared to other Belgian caves where values up to 15000 ppmv are measured for cave air $\mathrm{CO}_{2}$ (Verheyden, 2001; Ek and Godissart, 2014), the $\mathrm{CO}_{2}$ content in the Salledu-Dôme chamber, which hardly ever reaches 1000 ppmv, indicates that exchanges between cave air and external air must be relatively important. The Lesse river and the connections of the Salle-du-Dôme with neighboring chambers are most probably influencing the cave ventilation. In the Salle-duDôme, $\mathrm{CO}_{2}$ values fall close to outside air $p \mathrm{CO}_{2}$, and values of 400 to $600 \mathrm{ppmv}$ are measured during much of the year (Fig. 2g). Only during summer, higher $p \mathrm{CO}_{2}$ values up to $1000 \mathrm{ppmv}$ are measured in the chamber, which corresponds 
to the often observed summer increase in cave air $p \mathrm{CO}_{2}$ (Baker and Genty, 1998; Spötl et al., 2005; Riechelmann et al., 2011). In general, even higher amplitude variations are observed in most seasonal dynamically ventilated caves, such as St Michael's cave in Gibraltar with values varying between 500 and 6000 ppmv (Mattey et al., 2008), Obir Cave in Austria with values varying between 400 and 1500 ppmv (Spötl et al., 2005) Crag Cave (Ireland) with values between 1100 and 8000 ppmv (Baldini et al., 2008). In the Han-sur-Lesse cave, lower $p \mathrm{CO}_{2}$ values with smaller variation ranges are observed, similar to what is observed in year-round wellventilated caves such as Bunker Cave (Riechelmann et al., 2011). This confirms the former suggestion that the Han-surLesse cave air is most probably well mixed year-round due to good ventilation, due to the three known entrances and the Lesse river, which continuously flows through it. The difference between seasonally ventilated caves and year-round ventilated caves is also visible in the $\delta^{13} \mathrm{C}$ composition of the cave air (Riechelmann et al., 2011). The $\delta^{13} \mathrm{C}$ composition of the cave air in seasonally dynamically ventilated caves varies over a larger range around 10\%o (Spötl et al., 2005; Mattey et al., 2008) compared to year-round ventilated caves, such as Bunker Cave, where a variation range of only $3 \%$ is observed (Riechelmann et al., 2011). The Han-sur-Lesse cave displays a $\delta^{13} \mathrm{C}$ variation of $4 \%$, corresponding with a level that is expected for a year-round well-ventilated cave. Although the cave is well ventilated, a more negative $\delta^{13} \mathrm{C}$ signature of the $\mathrm{CO}_{2}$ air down to $-21.9 \%$ is measured in the Salle-du-Dôme in spring and summer (Fig. $2 \mathrm{~h}$ ), suggesting enhanced input of $\mathrm{C} 3$-plant-derived soil $\mathrm{CO}_{2}$ into the cave atmosphere.

Seasonal variations are also seen in the flow rates above the stalagmite, with less water dripping on the stalagmite during spring and summer (Fig. 2e). Drip rate monitoring in the Père Noël cave, which is part of the Han-sur-Lesse cave system, also demonstrated seasonal drip rate variations, with higher discharge amounts in winter compared to summer (Genty and Deflandre, 1998). This seasonal variation in discharge above the Han-sur-Lesse cave is mostly related to seasonal variations in evapotranspiration. This lowers the quantity of water feeding the epikarst during summer, reducing the amount of water that can reach the cave. In winter, the situation reverses: the activity of the vegetation cover diminishes and air temperatures lowers, reducing evapotranspiration, all of which allows more water to enter the soil and the epikarst. The pressure on the piston flow system is raised and more water is pushed into the cave, increasing the discharge above the stalagmite. Effective precipitation calculation of the Han-sur-Lesse karst aquifer indicates that from June to September the net evaporation or evapotranspiration is larger than the amounts of precipitation. The karst aquifer is thus only recharged during winter and spring: from October to May (Bonniver, 2011). This seasonal recharge is clearly visible in the evolution of the drip rate. A gradual decrease in drip rate occurs from June to November, while drip rate clearly increases from December to May (Fig. 2e).

\subsection{Seasonal variations in the $\mathrm{pH}$ and $\delta^{13} \mathrm{C}$ of the drip water}

The drip water $\mathrm{pH}$ and $\delta^{13} \mathrm{C}_{\mathrm{DIC}}$ display similar seasonal variations with an increase during summer and a decrease during winter. Synchronous seasonal variations in $\mathrm{pH}$ and $\delta^{13} \mathrm{C}_{\text {DIC }}$ driven by cave air $p \mathrm{CO}_{2}$ variations are commonly observed in caves (Spötl et al., 2005; Mattey et al., 2008). The degree of $\mathrm{CO}_{2}$ degassing can influence the $\mathrm{pH}$ and $\delta^{13} \mathrm{C}_{\mathrm{DIC}}$ of the drip water; removal of $\mathrm{CO}_{2}$ from the water during degassing increases its $\mathrm{pH}$, and removal of light ${ }^{12} \mathrm{C}$ isotopes from the drip water during degassing increases its $\delta^{13} \mathrm{C}_{\mathrm{DIC}}$. The degree of $\mathrm{CO}_{2}$ degassing of the drip water is mainly driven by the $p \mathrm{CO}_{2}$ difference between the cave air (with low $\mathrm{pCO}_{2}$ ) and the drip water (with high $\mathrm{pCO}_{2}$ ) (Mühlinghaus et al., 2009; Dreybrodt and Scholz, 2011; Deininger et al., 2012). This process is most pronounced in caves with a large seasonal variation in cave air $p \mathrm{CO}_{2}$ such as in the seasonally ventilated St Michael's Cave in Gibraltar (Mattey et al., 2008) or Obir Cave in Austria (Spötl et al., 2005). The monitoring data indicate that the similar seasonal variations of the drip water $\mathrm{pH}$ and $\delta^{13} \mathrm{C}_{\mathrm{DIC}}$ are not a response to the seasonal variations of cave air $p \mathrm{CO}_{2}$. The Han-sur-Lesse cave is a year-round well-ventilated cave with a much smaller $p \mathrm{CO}_{2}$ seasonal variation range, roughly between 400 and 1000 ppmv (Fig. 2g). If present in the Han-sur-Lesse cave, the effect of degree of $\mathrm{CO}_{2}$ degassing on the drip water $\mathrm{pH}$ and $\delta^{13} \mathrm{C}_{\mathrm{DIC}}$ is expected to be rather small. More important is that, if the degree of $\mathrm{CO}_{2}$ degassing is driving the $\mathrm{pH}$ and $\delta^{13} \mathrm{C}_{\text {DIC }}$ variations at the Proserpine drip site, they must anticorrelate with the $\mathrm{pH}$ and $\delta^{13} \mathrm{C}_{\mathrm{DIC}}$ of the drip water. Such anticorrelation is not visible in the results (Fig. 2f, g and i); the $p \mathrm{CO}_{2}$ peaks in summer, while the $\mathrm{pH}$ and $\delta^{13} \mathrm{C}_{\mathrm{DIC}}$ display a more gradual decrease. Furthermore, modeling results have shown that the effect of degree of $\mathrm{CO}_{2}$ degassing on the $\delta^{13} \mathrm{C}$ and $\mathrm{pH}$ of the drip water is negligible for fast drip sites such as the Proserpine (Mühlinghaus et al., 2009; Dreybrodt and Scholz, 2011; Deininger et al., 2012). The effect of degassing due to seasonal $p \mathrm{CO}_{2}$ variations in the cave air is thus most probably not driving the variations observed in the $\mathrm{pH}$ and the $\delta^{13} \mathrm{C}_{\text {DIC }}$ of the drip water.

Another factor that can seasonally increase both the $\mathrm{pH}$ and $\delta^{13} \mathrm{C}_{\mathrm{DIC}}$ of the drip water (and of the deposited calcite) is prior calcite precipitation (PCP). PCP is a common process occurring in karst aquifers (e.g., Fairchild et al., 2000, 2006; Verheyden et al., 2008a; Riechelmann et al., 2011). When downward-percolating water encounters a zone with lower $p \mathrm{CO}_{2}$, degassing occurs and calcite can precipitate. This process is enhanced during drier periods and lower discharge as aerated zones increase in the epikarst and residence time of the water becomes longer (Fairchild et al., 2000). The $\mathrm{CO}_{2}$ degassing in the epikarts causes both the $\delta^{18} \mathrm{O}$ and 
$\delta^{13} \mathrm{C}$ signals in the remaining water to increase. However, if the transition time of the solution until reaching the cave is longer than several days, the oxygen isotope equilibrium of the $\mathrm{CO}_{2}-\mathrm{H}_{2} \mathrm{O}-\mathrm{CaCO}_{3}$ system in the water is re-established again (Dreybrodt and Scholz, 2011). The net effect is thus an increase in $\delta^{13} \mathrm{C}$ and $\mathrm{pH}$ of the drip water, while no variation is visible in the $\delta^{18} \mathrm{O}$ of the drip water. Furthermore, effective precipitation data show that no water recharges the Han-surLesse epikarst between June and the end of September (Bonniver, 2011). This lower epikarst recharge is also visible in a decrease of drip flow between June and October (Fig. 2e). The decreased recharge of the epikarst is suggested to increase the aerated zone in the epikarst and thus enhance PCP gradually from June throughout September. The increase of recharge in winter decreases the effect of PCP, and the drip water $\mathrm{pH}$ and $\delta^{13} \mathrm{C}$ display a gradual decreasing trend. PCP is thus strongly suggested to cause the seasonal variations in $\mathrm{pH}$ and $\delta^{13} \mathrm{C}$ of the Proserpine drip water.

The occurrence of PCP can be indicated by an increased drip water $\delta^{13} \mathrm{C}$ composition compared to the soil water $\delta^{13} \mathrm{C}$ and/or by a negative relationship between the $\mathrm{Mg} / \mathrm{Ca}$ ratio or $\mathrm{Sr} / \mathrm{Ca}$ of the drip water and the $\mathrm{Ca}^{2+}$ concentration and drip rate (Fairchild and Treble, 2009). However, no data on the evolution of the $\mathrm{Ca}, \mathrm{Mg}$ or $\mathrm{Sr}$ concentration in the Proserpine drip water or the $\delta^{13} \mathrm{C}$ composition of the soil water are available, making it difficult to estimate the importance of the process. Another argument in support of the PCP effect is the formation of a stalactite above the stalagmite. However, during this formation of PCP, and due to the high drip rate of the Proserpine, the transition time is not long enough to re-establish the increased $\delta^{18} \mathrm{O}$ signal in the water and both the $\delta^{13} \mathrm{C}$ and the $\delta^{18} \mathrm{O}$ values of the drip water are increased (Dreybrodt and Scholz, 2011). Since the $\delta^{18} \mathrm{O}$ and $\delta^{13} \mathrm{C}$ signals of the Proserpine drip water evolve differently, stalactite growth can increase both signals but cannot be responsible for the seasonal variations. Furthermore, the drapery above the Proserpine is estimated to be about 0.5 to $1 \mathrm{~m}$ long and is thus rather small compared to the 2 to $3 \mathrm{~m}$ height of the Proserpine stalagmite, which displays very high growth rates up to $2 \mathrm{~mm} \mathrm{yr}^{-1}$ (Verheyden et al., 2006). It is thus not certain whether the stalactite is actively growing in present times. Also, due to the continuous water flow, calcite will most probably not have the time to precipitate stalactite calcite before falling on the stalagmite. Dating and analysis of the stalactite above the Proserpine would provide the missing information. However, its location $30 \mathrm{~m}$ above the Proserpine makes it difficult to be sampled.

In summary, the cave system is subdivided into a "winter mode" lasting from December to June and a "summer mode" from June to December (Fig. 2). During the winter mode, cave air and drip water temperature and $p \mathrm{CO}_{2}$ are low and $\delta^{13} \mathrm{C}$ values of the cave air $\mathrm{CO}_{2}$ are high. The plant coverage above the cave inactively facilitates water recharge of the epikarst reservoir, leading to a decrease of PCP, which gradually decreases the $\mathrm{pH}$ and the $\delta^{13} \mathrm{C}_{\mathrm{DIC}}$ of the drip wa- ter. During the summer mode, cave air and drip water temperatures increase, the $p \mathrm{CO}_{2}$ increases and the $\delta^{13} \mathrm{C}$ values of the cave air $\mathrm{CO}_{2}$ decrease. The plant coverage above the cave reactivates, leading to lower water recharge, which enhances the PCP effect, leading to increased $\mathrm{pH}$ and $\delta^{13} \mathrm{C}_{\mathrm{DIC}}$ values in the drip water.

\subsection{The $\delta^{18} \mathrm{O}$ of the precipitated calcite reflects temperature variations}

The $\delta^{18} \mathrm{O}$ of calcite deposited on the glass slabs varies seasonally with more negative values during summer (Fig. 21). If the calcite is deposited in isotopic equilibrium with its drip water, these variations can be caused by changes in the $\delta^{18} \mathrm{O}$ of the drip water and/or by changes in temperature that affect the fractionation factor between the drip water and the precipitating calcite (Dreybrodt and Scholz, 2011). If not deposited in equilibrium, the seasonal $\delta^{18} \mathrm{O}$ variations on the glass slabs would be due to disequilibrium effects that require further investigation.

A first step in understanding the $\delta^{18} \mathrm{O}$ system of the Salledu-Dôme demands determining whether the calcite is deposited in equilibrium or not. In speleothems, this is traditionally done by applying the Hendy test (Hendy, 1971), which compares the $\delta^{18} \mathrm{O}$ and $\delta^{13} \mathrm{C}$ values in the center of the stalagmite with those on the sides within a single growth layer. However, since we work on a drill core taken "in the middle" of a 1-2 m wide speleothem, the Hendy test cannot be applied. As an alternative, we calculated equilibrium conditions of the deposited calcite using the calcite-water fractionation factor. Different authors have proposed fractionation factors based on three different approaches, summarized in Table 1.

The first approach, using laboratory experiments, has been tested in different studies, each giving another value for a water-calcite fractionation factor. The most-used laboratoryestablished fractionation factors remain the ones by O'Neil et al. (1969) later modified by Friedman and O’Neil (1977), the relationship of Kim and O'Neil (1997) later modified by Kim et al. (2007), and the results of Tarutani et al. (1969) and of Jimenez-Lopez et al. (2001) (Table 1). A second approach to determine fractionation factors is established by using theoretical models such as the ones from Horita and Clayton (2007) and from Chacko and Deines (2008). A third approach consists of using cave-monitoring data to make an average of the in-cave-observed fractionation factors (Demeny et al., 2010; Tremaine et al., 2011). Tremaine et al. (2011) established such a "cave calcite" relationship by doing a best fit through the data on a large number of modern caves at different latitudes, altitudes and temperatures.

Applying the different fractionation factors to our data shows that the measured $\delta^{18} \mathrm{O}$ signals of the glass-slab calcite correspond within $1 \%$ with the calculated values, suggesting that it is deposited close to equilibrium with the drip water (Table 2). However, variations occur between the results 
Table 1. A selection of the most commonly used water-calcite oxygen fractionation factors. Laboratory and theoretical approaches differ from the relationships found in cave settings.

\begin{tabular}{lllc}
\hline Author & Method & $1000 \times \ln \alpha$ & $\mathrm{d} \alpha / \mathrm{d} T\left(\% 0^{\circ} \mathrm{C}^{-1}\right)$ \\
\hline $\begin{array}{l}\text { O'Neil et al. (1969) modified } \\
\text { by Friedman and O'Neil (1977) }\end{array}$ & Laboratory & $2.78\left(10^{6} T^{-2}\right)-2.89$ & -0.24 \\
$\begin{array}{l}\text { Kim and O'Neil (1997) modified } \\
\text { by Kim et al. (2007) }\end{array}$ & Laboratory & $18.03\left(10^{6} T^{-2}\right)-31.17$ & -0.22 \\
$\begin{array}{l}\text { Chacko and Deines (2008) constructed } \\
\text { relation by Tremaine et al. (2011) }\end{array}$ & Theoretical calculation & $2.57333\left(10^{6} T^{-2}\right)-0.869$ & -0.22 \\
Horita and Clayton (2007) & $\begin{array}{l}\text { Calculations compared with } \\
\text { experimental results }\end{array}$ & $0.9521\left(10^{6} T^{-2}\right)+11.59\left(10^{3} T^{-1}\right)-21.56$ & -0.23 \\
Tremaine et al. (2011) & $\begin{array}{l}\text { Linear best fit through large } \\
\text { number of cave studies } \\
\text { Cave-monitoring results }\end{array}$ & $(16.01 \pm 0.65) \times\left(10^{3} T^{-1}\right)-(24.6 \pm 2.2)$ & -0.18 \\
Demeny et al. (2010) & Hungarian cave & $17500 \times T^{-1}-29.89$ & -0.22 \\
& & & \\
\hline
\end{tabular}

derived from different methods. Among the laboratoryestablished relationships, that of O'Neil et al. (1969) modified by Friedmann and O'Neil (1977) best corresponds to our observations with on average $0.25 \%$ difference with the values measured on the glass slabs. This is also confirmed in other studies where this experimental fractionation factor is considered to give the best approximation for in-cave observations (McDermott et al., 2005; Riechelmann et al., 2013). The theoretical values (Horita and Clayton, 2007; Chacko and Deines, 2008) suggest a more negative $\delta^{18} \mathrm{O}$ composition for the deposited calcites. This is also the case for other studies where theoretical results seem to overestimate the fractionation factor (Demeny et al., 2010; Tremaine et al., 2011). For our results the best agreement is found by applying the Tremaine et al. (2011) fractionation factor, which is not surprising since the latter is based on experimental studies on calcite formed in caves. However, the good match between the measured values and those calculated from the Tremaine et al. (2011) relationship does not constitute a proof of equilibrium condition. The fractionation factor from Tremaine et al. (2011) is derived from the natural system, and it is questionable whether real equilibrium does exist in nature.

The small difference between the measured data and the O'Neil et al. (1969) relationship modified by Friedmann and O'Neil (1977) indicates that the deposition of calcite occurs near oxygen isotopic equilibrium in the Salle-du-Dôme. Seasonal variations of $\delta^{18} \mathrm{O}$ observed in calcite are likely caused by variations in the drip water $\delta^{18} \mathrm{O}$ composition and/or in the temperature-dependent fractionation factor (Fairchild et al., 2006). However, within analytical uncertainty, the $\delta^{18} \mathrm{O}$ composition of the drip water remains constant throughout the year. Consequently, variations in the fractionation factor due to temperature changes in the cave air likely explain the seasonal pattern seen in the $\delta^{18} \mathrm{O}$ composition of the glass slab. If the most commonly accepted temperature dependence of the water-calcite fractionation factor for the oxygen isotopes of $0.247 \% \circ 1^{\circ} \mathrm{C}^{-1}$ (O’Neil et al., 1969) is used, our mea- sured net difference of the $\delta^{18} \mathrm{O}$ values of the glass-slab calcite (i.e., $\delta^{18} \mathrm{O}$ range of the glass-slab calcite minus the $\delta^{18} \mathrm{O}$ range of the drip water) of $0.58 \%$ would result from a $2.3{ }^{\circ} \mathrm{C}$ variation in the drip water temperature. This temperature corresponds well with the $2-2.5^{\circ} \mathrm{C}$ temperature range measured in the drip waters. This correspondence constitutes a strong confirmation of both the isotopic equilibrium and the temperature dependence of the calcite $\delta^{18} \mathrm{O}$.

To summarize, the $\delta^{18} \mathrm{O}$ composition of the glass-slab calcite (Fig. 21) is deposited very close to equilibrium with its drip water. Seasonal variations in $\delta^{18} \mathrm{O}$ composition of the calcite on the glass slabs are caused by the very similar seasonal temperature variation of the cave air and the drip water (Fig. 2c and d). A temperature increase of $1^{\circ} \mathrm{C}$ corresponds with a decrease of $0.20 \%$ in isotopic composition of the deposited calcite. The warmer the cave air, the more negative the $\delta^{18} \mathrm{O}$ composition of the formed calcite. No disequilibrium processes are active, as they would shift the isotopic composition to heavier values with increasing temperature.

\subsection{The calcite $\delta^{13} \mathrm{C}$ reflects equilibrium conditions and is driven by PCP}

The carbon isotopic composition of calcite deposited in equilibrium with its drip water depends on (i) the $\delta^{13} \mathrm{C}$ of the DIC in the drip water and (ii) the temperature-dependent fractionation factor between the DIC and the deposited calcite for a $\mathrm{pH}$ range around 7 . The average $\delta^{13} \mathrm{C}$ values of the DIC in the Han-sur-Lesse drip water (Fig. 2i) display a seasonality between $-12.2 \%$ at the end of winter and $-11 \%$ at the end of summer. The $\delta^{13} \mathrm{C}$ of the deposited glass-slab calcite are on average $1 \%$ o heavier than the $\delta^{13} \mathrm{C}$ of the drip water and display similar seasonal variations $(r=0.62$ and $p=0.0017)$. The fractionation factor between the DIC and the deposited calcite as determined by Emrich et al. (1970) and Dulinski and Rozanki (1990) are estimated to correspond best with the natural speleothem depositional conditions, and 
Table 2. Calculated $\delta^{18} \mathrm{O}$ values for calcite deposited in equilibrium with its drip water for different authors. Values were calculated using the average drip water composition of $-7.65 \%$ or the lowest, highest and average measured temperatures at the Salle-du-Dôme. The second part of the table shows the difference between the calculated $\delta^{18} \mathrm{O}$ values and the $\delta^{18} \mathrm{O}$ values measured on the glass slabs. Best results are given by the "in-cave" relationship of Tremaine et al. (2011).

\begin{tabular}{lrrr|rrr}
\hline$\delta^{18} \mathrm{O}_{\text {DripWater }}=-7.65 \% o$ & \multicolumn{3}{c|}{ Predicted $\delta^{18} \mathrm{O}$} & \multicolumn{3}{c}{ Difference with glass-slab values } \\
& $T_{\min }$ & $T_{\operatorname{mid}}$ & $T_{\max }$ & $\delta^{18} \mathrm{O}_{\min }$ & $\delta^{18} \mathrm{O}_{\operatorname{mid}}$ & $\delta^{18} \mathrm{O}_{\max }$ \\
Author & $10.5^{\circ} \mathrm{C}$ & $12^{\circ} \mathrm{C}$ & $14.5^{\circ} \mathrm{C}$ & -6.25 & -6.55 & -6.98 \\
\hline O'Neil et al. (1969) & -6.44 & -6.80 & -7.39 & 0.19 & 0.25 & 0.41 \\
modified by Friedmann and O'Neil (1977) & & & & & & -0.39 \\
Kim and O'Neil (1997) & -5.71 & -6.04 & -6.59 & -0.54 & -0.51 & \\
modified by Kim et al. (2007) & -6.96 & -7.30 & -7.85 & 0.71 & 0.75 & 0.87 \\
Horita and Clayton (2007) & -6.98 & -7.32 & -7.86 & 0.73 & 0.77 & 0.88 \\
Chacko and Deines (2008) & -6.30 & -6.62 & -7.15 & 0.05 & 0.07 & 0.17 \\
Demeny et al. (2010) & $-6.26 \pm 0.09$ & $-6.55 \pm 0.08$ & $-7.04 \pm 0.06$ & $0.01 \pm 0.09$ & $0 \pm 0.08$ & $0.06 \pm 0.06$ \\
Tremaine et al. (2011) & & & & & & \\
\hline
\end{tabular}

both suggest $\varepsilon$ values around $1 \%$ for temperatures between 5 and $20^{\circ} \mathrm{C}$. The $1 \%$ enrichment of the $\delta^{13} \mathrm{C}$ calcite on the glass slabs compared to the drip water $\delta^{13} \mathrm{C}$ indicates that the $\delta^{13} \mathrm{C}$ is deposited in equilibrium with the drip water.

Our hypothesis that the deposition of the calcite occurs in isotopic equilibrium is also confirmed by the different evolution of the $\delta^{18} \mathrm{O}$ (Fig. 2l) and the $\delta^{13} \mathrm{C}$ (Fig. $2 \mathrm{~m}$ ) values of the glass-slab calcite, which indicates that both proxies evolve independently under the influence of different factors. Emrich et al. (1970) and Dulinski and Rozanki (1990) both suggest a small temperature dependence of the fractionation factor of about $0.07 \%{ }^{\circ} \mathrm{C}$. The $\sim 2.5^{\circ} \mathrm{C}$ seasonal temperature variation in the Salle-Du-Dôme causes a change of hardly $0.17 \%$ in the calcite composition. The seasonal temperature variations are thus too small to significantly influence the carbon fractionation factor and thus the isotopic composition of the deposited calcite. Furthermore typical disequilibrium effects such as increased drip interval and stronger $p \mathrm{CO}_{2}$ degassing of the drip water due to longer residence times have been shown not to affect the $\delta^{13} \mathrm{C}$ of calcite deposited under fast-flow sites (Dreybrodt and Scholz, 2011; Deininger et al., 2012). The $\delta^{13} \mathrm{C}$ composition of the deposited Proserpine calcite is thus considered deposited in equilibrium with the drip water. The seasonal variations in calcite $\delta^{13} \mathrm{C}$ are caused by seasonal variations in the drip water $\delta^{13} \mathrm{C}$, which relates probably to the intensity of PCP.

\subsection{Variations in the $\delta^{18} \mathrm{O}$ and $\delta^{13} \mathrm{C}$ of the stalagmite reflect seasonal variations}

The Proserpine stalagmite displays clear lamination formed by alternating dark, compact layers and white, more porous layers (Verheyden et al., 2006). The seasonal character of the layering in the Proserpine stalagmite, with one dark and one white layer deposited every year, was already demonstrated by Verheyden et al. (2006). However, these authors were not able to determine the correspondence between layer type and season. In our studied core, 10 additional layer couplets (= dark + white layer) can be counted, compared to the Proserpine core of Verheyden et al. (2006) drilled in 2001. The 10 additional layer couplets, counted over a period of 10 years, confirm that one layer couplet is deposited every year. Layer couplets establish the age model of the laminated part of the stalagmite. Twenty-six layer couplets are counted from the top of the stalagmite to the start of the isotope sampling, indicating that the youngest analyzed layer formed in 1985 AD. The isotopic measurements were conducted on nine consecutive layer couplets and consequently run from 1985 to 1976 AD (Fig. 5).

A first conclusion from the isotopic analyses of the individual layers is that the $\delta^{13} \mathrm{C}$ and $\delta^{18} \mathrm{O}$ signals display an opposite behavior within one layer (Fig. 4). When the $\delta^{13} \mathrm{C}$ signal reaches its maximum value at the end of a dark layer, the $\delta^{18} \mathrm{O}$ value arrives at its minimum value. This anticorrelation is also seen in the cave-monitoring results where $\delta^{13} \mathrm{C}$ values increase through summer while the $\delta^{18} \mathrm{O}$ values are low. This indicates that dark layers are most probably deposited in summer, while light layers are formed in winter. Furthermore, a link between the variation range of the $\delta^{13} \mathrm{C}$ and $\delta^{18} \mathrm{O}$ signals and the color intensity of a layer (darker dark layers or lighter white layers) may be possible. The layers around 1977 AD display a stronger visual color contrast between dark and white layers compared to the layers around 1985 AD (Fig. 4). In parallel, a larger difference in the isotopic composition of two consecutive layers is observed for that year. More compact and darker layers have more negative $\delta^{18} \mathrm{O}$ and more positive $\delta^{13} \mathrm{C}$ values while whiter and more porous layers have more negative $\delta^{13} \mathrm{C}$ and more positive $\delta^{18} \mathrm{O}$ values.

The difference in calcite between white and dark may possibly be related to seasonal changes in growth rate of the calcite. The mean annual growth rate of speleothems primarily depends on the drip water calcium ion concentration (Genty et al., 2001). In addition, there is a correlation between the 


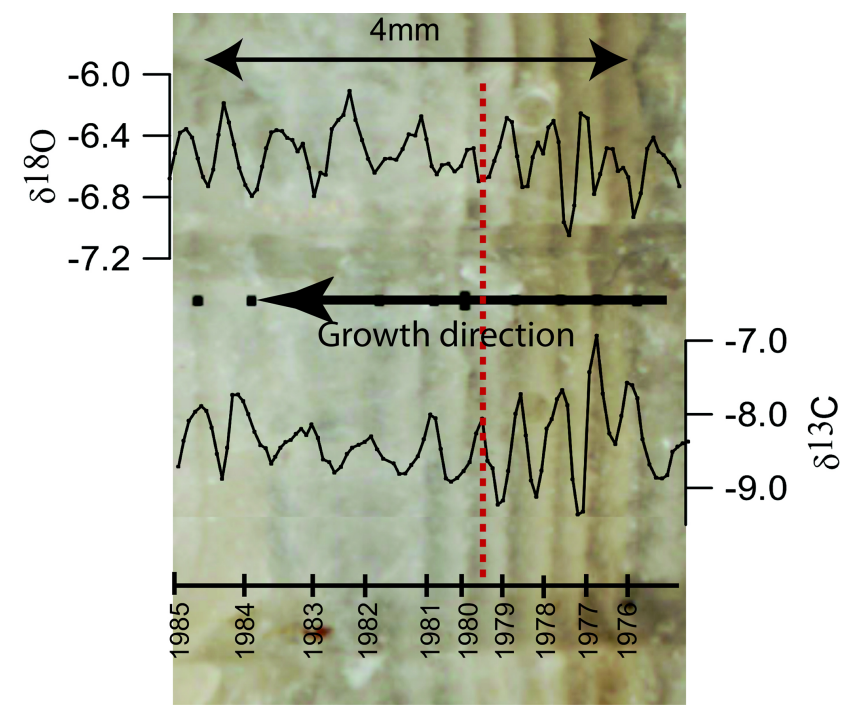

Figure 4. The $\delta^{18} \mathrm{O}$ and $\delta^{13} \mathrm{C}$ signals, reported in per mill VPDB, from the Proserpine stalagmite anticorrelate at monthly scale. Note that, in the scanned figure of the Proserpine slab, dark and compact layers become whiter due to the translucent light of the scan while the white and porous layers become dark. At the end of a dark compact layer (dotted line), the $\delta^{18} \mathrm{O}$ values reach their minimum values, while the $\delta^{13} \mathrm{C}$ values reach their maximum. Dark layers are formed during summer, when cave temperatures are high (leading the low $\delta^{18} \mathrm{O}$ ) and PCP increases (leading to high $\delta^{13} \mathrm{C}$ ). The clearer the lamination, the larger the amplitude of the variations in the isotopic composition.

measured growth rate and the temperature due to the interrelationship between calcium ion concentration, soil $p \mathrm{CO}_{2}$ and surface temperature. However, the latter link is not always true since PCP and/or lack of soil cover can decrease the calcium ion concentration of the water and still represent high temperatures (Genty et al., 2001). Discharge also affects growth rate but is more pronounced for slowly dripping sites. For faster-drip sites, such as the Proserpine, calcite saturation index is the main factor driving the growth rate changes (Genty et al., 2001). Unfortunately, no data on the seasonal evolution of the calcite saturation index at the Proserpine grow site are available. However, seasonal variations in the drip water $\delta^{13} \mathrm{C}$ values of the Proserpine have shown that PCP affects its geochemistry in summer. PCP lowers the calcite saturation index (Genty et al., 2001; Riechelmann et al., 2013). The increase of the PCP effect in summer strongly suggests that the Proserpine summer water contains less dissolved $\mathrm{Ca}^{2+}$, which may be responsible for a decreased growth rate in summer.

The observations gained from combined monitoring observation and stable isotopic analyses answer the remaining question in Verheyden et al. (2006). Darker layers reflect summer cave conditions, and white layers reflect winter cave conditions. In addition, in the summer, the probably lower calcite saturation index of the drip water due to

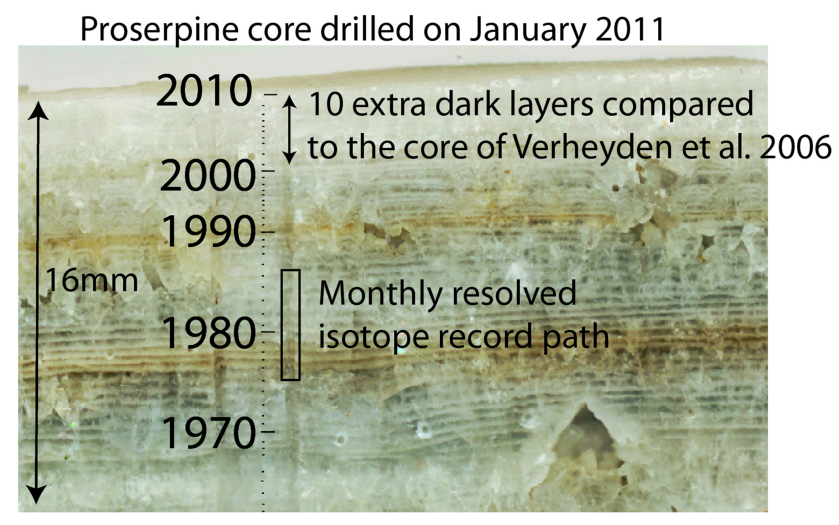

Figure 5. Detail of the upper $16 \mathrm{~mm}$ of the Proserpine core drilled in 2011. Ten additional dark layers are counted compared to the core of Verheyden et al. (2006), confirming the seasonal character of the layering. Ages are based on layer counting, with one dark and one white layer deposited every year. The frame indicates the location of the monthly resolved $\delta^{18} \mathrm{O}$ and $\delta^{13} \mathrm{C}$ measurements.

enhanced PCP causes a decreased in the calcite growth rate in the speleothem. Darker and more compact calcite is suggested to reflect slower growth rate conditions. Further investigation in the seasonal cycle of the carbonate-dissolved ion concentration of the Proserpine drip water is necessary to confirm this hypothesis.

\section{Conclusions}

Through a biweekly cave monitoring and a high-resolution stable isotopic record of a recent finely laminated part of a growing speleothem, the seasonal variation of the cave environment and how these parameters are recorded in the speleothem proxies are documented.

1. The temperature effect clearly influences the $\delta^{18} \mathrm{O}$ and $\delta \mathrm{D}$ composition of the rainwater with increasing values during the summer months. The $\delta^{18} \mathrm{O}$ and $\delta \mathrm{D}$ composition of the drip water remains constant, indicating a long residence time of the water in the epikarst and a well-mixed aquifer. A residence time of more than one year is assumed with the first waters percolating into the cave 5 to 6 months after entering the soil. Such long water residence time in the epikarst combined with a reaction time of $24 \mathrm{~h}$ to a heavy-rainfall event indicates a piston flow hydrology in the epikarst.

2. The records of the different measured factors in and outside the cave suggest that the physico-chemical behavior of the Han-sur-Lesse cave closely responds to the seasonally varying external climate. The cave interior climatology varies between a summer mode lasting from June to December and a winter mode from December to June. During the summer mode, the cave air and drip water temperatures are higher, the drip flow 
decreases the cave air $p \mathrm{CO}_{2}$ increases. During the winter mode the temperature cools down and the vegetation cover becomes less active, leading to an opposite behavior of the measured factors compared to the summer mode.

3. Seasonal variation in drip water $\mathrm{pH}$ and $\delta^{13} \mathrm{C}$ value most probably relate to the seasonality in PCP intensity, driven by seasonal changes in water discharge. During summer, lower recharge will cause stronger PCP, which gradually increases the $\mathrm{pH}$ and $\delta^{13} \mathrm{C}$ composition of the drip water between June and September. In winter, the vadose zone gets recharged with water and PCP decreases. The $\mathrm{pH}$ and $\delta^{13} \mathrm{C}$ composition of the drip water decreases gradually from October trough May.

4. Calcite precipitated on glass slabs indicates more negative $\delta^{18} \mathrm{O}$ and more positive $\delta^{13} \mathrm{C}$ values in summer. Both isotopic signals are deposited in equilibrium with their drip water. The seasonal variations of the $\delta^{18} \mathrm{O}$ values of precipitated calcite are caused by the seasonal temperature variations inside the cave. The seasonal variations of the $\delta^{13} \mathrm{C}$ values are mainly controlled by the seasonal variation in drip water $\delta^{13} \mathrm{C}$ caused by seasonally varying PCP.

5. The studied part of the Proserpine stalagmite displays seasonal layering with one dark and one white layer deposited every year. The opposite seasonal behavior of the $\delta^{18} \mathrm{O}$ and the $\delta^{13} \mathrm{C}$ signals on the glass slabs is also visible in the isotopic signals of the individual layers in the stalagmite. Dark layers have low $\delta^{18} \mathrm{O}$ and high $\delta^{13} \mathrm{C}$ values, while white layers have high $\delta^{18} \mathrm{O}$ and low $\delta^{13} \mathrm{C}$ values. Dark layers are formed during the cave's summer mode, while white layers grow calcite during the cave's winter mode. The clearer the lamination and coloring of the layers, the larger the amplitudes of the variations in the isotopic composition.

Acknowledgements. We thank the "Domaine des Grottes de Han" for allowing us to sample the stalagmite and visit the cave on a biweekly basis, Etienne Lannoy for sampling the rain and drip water during the monitoring period, Claire Mourgues and David Verstraeten for the help in the lab and Mr. Van Dierendonck for his interest and support. P. Claeys thanks the Hercules Foundation and Research Foundation Flanders (FWO, project G-0422-10).

Edited by: J. Guiot

\section{References}

Baker, A. and Genty, A.: Environmental pressures on conserving cave speleothems: effects of changing surface land use and increased cave tourism, J. Environ. Manage., 53, 165-175, 1998.

Baker, A., Genty, D., Dreybrodt, W., Barnes, W. L., Mockler, N. J., and Grapes, J.: Testing theoretically predicted stalagmite growth rate with Recent annually laminated samples: implications for past stalagmite deposition, Geochim. Cosmochim. Ac., 62, 393 404, 1998.

Baker, A., Asrat, A., Fairchild, I. J., Leng, M. J., Wynn, P. M., Bryant, C., Genty, D., and Umer, M.: Analysis of the climate signal contained within delta $\mathrm{O}-18$ and growth rate parameters in two Ethiopian stalagmites, Geochim. Cosmochim. Ac., 71, 2975-2988, 2007.

Baldini, J. U. L., McDermott, F., Hoffmann, D. L., Richards, D. A., and Clipson, N.: Very high-frequency and seasonal cave atmosphere $p \mathrm{CO}_{2}$ variability: Implications for stalagmite growth and oxygen isotope-based paleoclimate records, Earth Planet. Sci. Lett., 272, 118-129, 2008

Bonniver, I.: Etude Hyrogeologique et dimmensionnement par modelisation du "systeme-tracage" du reseau karstique the Hansur-Lesse (Massif de Boine, Belgique), 2011, Geologie, FUNDP Namur, Namur, 93-97, 2011.

Chacko, T. and Deines, P.: Theoretical calculation of oxygen isotope fractionation factors in carbonate systems, Geochim. Cosmochim. Ac., 72, 3642-3660, 2008.

Deininger, M., Fohlmeister, J., Scholz, D., and Mangini, A.: Isotope disequilibrium effects: The influence of evaporation and ventilation effects on the carbon and oxygen isotope composition of speleothems - A model approach, Geochim. Cosmochim. Ac., 96, 57-79, 2012.

Delvaux De Fenffe, D.: Geologie et tectonique du Parc de Lesse et Lomme au bord sud du Bassin de Dinant (Rochefort, Belgique), Bulletins de la Societe Belge de Geologie, 94, 81-95, 1985.

Demeny, A., Kele, S., and Siklosy, Z.: Empirical equations for the temperature dependence of calcite-water oxygen isotope fractionation from 10 to $70^{\circ} \mathrm{C}$, Rapid Commun. Mass Sp., 24, 35213526, 2010.

Dreybrodt, W.: Chemical kinetics, speleothem growth and climate, Boreas, 28, 347-356, 1999.

Dreybrodt, W.: Evolution of the isotopic composition of carbon in a calcite precipitating $\mathrm{H}_{2} \mathrm{O}-\mathrm{CO}_{2}-\mathrm{CaCO}_{3}$ solution and the related isotopic composition of calcite in stalagmites, Geochim. Cosmochim. Ac., 72, 4712-4724, 2008.

Dreybrodt, W. and Scholz, D.: Climatic dependence of stable carbon and oxygen isotope signals recorded in speleothems: From soil water to speleothem calcite, Geochim. Cosmochim. Ac., 75 , 734-752, 2011.

Dulinski, M. and Rozanski, K.: Formation of ${ }^{12} \mathrm{C} /{ }^{13} \mathrm{C}$ isotope ratios in spsleothems: a semi-dynamic model, Radiocarbon, 32, 7-16, 1990.

Ek, C. and Godissart, J.: Carbon dioxide in cave air and soil air in some karstic areas of Belgium, A prospective view, Geolog. Belgica, 17, 102-106, 2014.

Emrich, K., Ehhalt, D. H., and Volgel, J. C.: Carbon isotope fractionation during the precipitation of calciumcarbonates, Earth Planet. Sci. Lett., 8, 363-371, 1970.

Fairchild, I. J., Borsato, A., Tooth, A. F., Frisia, S., Hawkesworth, C. J., Huang, Y. M., McDermott, F., and Spiro, B.: Controls on 
trace element ( $\mathrm{Sr}-\mathrm{Mg}$ ) compositions of carbonate cave waters: implications for speleothem climatic records, Chem. Geol., 166, 255-269, 2000.

Fairchild, I. J., Smith, C. L., Baker, A., Fuller, L., Spotl, C., Mattey, D., McDermott, F., and Eimp: Modification and preservation of environmental signals in speleothems, Earth-Sci. Rev., 75, 105-153, 2006.

Fairchild, I. J. and Treble, P. C.: Trace elements in speleothems as recorders of environmental change, Quat. Sci. Rev., 28, 449-468, 2009.

Friedman, I. and O'Neil, J. R.: Compilation of stable isotope fractionation factors of geochemical interest, Geolog. Surv. Prof. Paper 440-KK, 177, 1977.

Genty, D., Baker, A., and Vokal, B.: Intra- and inter-annual growth rate of modern stalagmites, Chem. Geol., 176, 191-212, 2001.

Genty, D., Blamart, D., Ouahdi, R., Gilmour, M., Baker, A., Jouzel, J., and Van-Exter, S.: Precise dating of DansgaardOeschger climate oscillations in western Europe from stalagmite data, Nature, 421, 833-837, 2003.

Genty, D. and Deflandre, G.: Drip flow variations under a stalactite of the Pere Noel cave (Belgium). Evidence of seasonal variations and air pressure constraints, J. Hydrol., 211, 208-232, 1998.

Genty, D. and Quinif, Y.: Annually laminated sequences in the internal structure of some Belgian stalagmites - Importance for paleoclimatology, J. Sediment. Res., 66, 275-288, 1996.

Hendy, C. H.: Isotopic geochemistry of speleothems: 1. Calculations of effects on different modes of formation on isotopic composition of speleothems and their applicability as paleoclimatic indicators, Geochim. Cosmochim. Ac., 35, 801-824, 1971.

Horita, J. and Clayton, R. N.: Comment on the studies of oxygen isotope fractionation between calcium carbonates and water at low temperatures by Zhou and Zheng (2003, 2005), Geochim. Cosmochim. Ac., 71, 3131-3135, 2007.

Jimenez-Lopez, C., Caballero, E., Huertas, F. J., and Romanek, C. S.: Chemical, mineralogical and isotope behavior, and phase transformation during the precipitation of calcium carbonate minerals from intermediate ionic solution at $25^{\circ} \mathrm{C}$, Geochim. Cosmochim. Ac., 65, 3219-3231, 2001.

Jochum, K. P., Scholz, D., Stoll, B., Weis, U., Wilson, S. A., Yang, Q., Schwalb, A., Boerner, N., Jacob, D. E., and Andreae, M. O.: Accurate trace element analysis of speleothems and biogenic calcium carbonates by LA-ICP-MS, Chem. Geol., 318, 31-44, 2012.

Kim, S.-T., Mucci, A., and Taylor, B. E.: Phosphoric acid fractionation factors for calcite and aragonite between 25 and $75^{\circ} \mathrm{C}$ : revisited, Chem. Geol., 246, 135-146, 2007.

Kim, S. T. and O'Neil, J. R.: Equilibrium and nonequilibrium oxygen isotope effects in synthetic carbonates, Geochim. Cosmochim. Ac., 61, 3461-3475, 1997.

Kluge, T., Riechelmann, D. F. C., Wieser, M., Spötl, C., Sultenfuss, J., Schroder-Ritzrau, A., Niggemann, S., and Aeschbach-Hertig, W.: Dating cave drip water by tritium, J. Hydrol., 394, 396-406, 2010.

Kottek, M., Grieser, J., Beck, C., Rudolf, B., and Rubel, F.: World map of the Koppen-Geiger climate classification updated, Meteorologische Zeitschrift, 15, 259-263, 2006.

Lachniet, M. S.: Climatic and environmental controls on speleothem oxygen-isotope values, Quat. Sci. Rev., 28, 412-432, 2009.
Mattey, D., Lowry, D., Duffet, J., Fisher, R., Hodge, E., and Frisia, S.: A 53 year seasonally resolved oxygen and carbon isotope record from a modem Gibraltar speleothem: Reconstructed drip water and relationship to local precipitation, Earth Planet. Sci. Lett., 269, 80-95, 2008.

McDermott, F.: Centennial-scale Holocene climate variability revealed by a high-resolution speleothem $\delta^{18} \mathrm{O}$ record from SW Ireland (9 November, pg 1328, 2001), Science, 309, 1816-1816, 2005.

McDermott, F., Schwarcz, H. P., and Rowe, P. J.: Isotopes in speleothems, in: Isotopes in Paleoenvironmental Research, edited by: Leng, M. J., Springer Netherlands, 185-226, 2005.

Miorandi, R., Borsato, A., Frisia, S., Fairchild, I. J., and Richter, D. K.: Epikarst hydrology and implications for stalagmite capture of climate changes at Grotta di Ernesto (NE Italy): results from long-term monitoring, Hydrol. Proc., 24, 3101-3114, 2010.

Mühlinghaus, C., Scholz, D., and Mangini, A.: Modelling stalagmite growth and $\delta^{13} \mathrm{C}$ as a function of drip interval and temperature, Geochim. Cosmochim. Ac., 71, 2780-2790, 2007.

Mühlinghaus, C., Scholz, D., and Mangini, A.: Modelling fractionation of stable isotopes in stalagmites, Geochim. Cosmochim. Ac., 73, 7275-7289, doi:10.1016/j.gca.2009.09.010, 2009.

O'Neil, J. R., Clayton, R. N., and Mayeda, T. K.: Oxygen isotope fractionation in divalent metal carbonates J. Chem. Phys., 51, 5547-5558, 1969

Oster, J. L., Montanez, I. P., and Kelley, N. P.: Response of a modern cave system to large seasonal precipitation variability, Geochim. Cosmochim. Ac., 91, 92-108, 2012.

Piccini, L., Zanchetta, G., Drysdale, R. N., Hellstrom, J., Isola, I., Fallick, A. E., Leone, G., Doveri, M., Mussi, M., Mantelli, F., Molli, G., Lotti, L., Roncioni, A., Regattieri, E., Meccheri, M., and Vaselli, L.: The environmental features of the Monte Corchia cave system (Apuan Alps, central Italy) and their effects on speleothem growth, International Journal of Speleology, 37, 153-172, 2008.

Quinif, Y.: Une nouvelle topographie de la Grotte de Han, Lapiaz hors serie "Special Han", 15-18, 1988.

Riechelmann, D. F. C., Deininger, M., Scholz, D., Riechelmann, S., Schroeder-Ritzrau, A., Spoetl, C., Richter, D. K., Mangini, A., and Immenhauser, A.: Disequilibrium carbon and oxygen isotope fractionation in recent cave calcite: Comparison of cave precipitates and model data, Geochim. Cosmochim. Ac., 103, 232-244, 2013.

Riechelmann, D. F. C., Schroeder-Ritzrau, A., Scholz, D., Fohlmeister, J., Spoetl, C., Richter, D. K., and Mangini, A.: Monitoring Bunker Cave (NW Germany): A prerequisite to interpret geochemical proxy data of speleothems from this site, J. Hydrol., 409, 682-695, 2011.

Rozanski, K., Araguasaraguas, L., and Gonfiantini, R.: Relationship between long-term trends of ${ }^{18} \mathrm{O}$ isotope composition of precipitation and climate, Science, 258, 981-985, 1992.

Ruan, J. and Hu, C.: Seasonal variations and environmental controls on stalagmite calcite crystal growth in Heshang Cave, Central China, Chinese Sci. Bull., 55, 3929-3935, 2010.

Scholz, D., Muehlinghaus, C., and Mangini, A.: Modelling $\delta^{13} \mathrm{C}$ and $\delta^{18} \mathrm{O}$ in the solution layer on stalagmite surfaces, Geochim. Cosmochim. Ac., 73, 2592-2602, 2009.

Smart, P. L. and Friedrich, H.: Water movement and storage in the unsaturated zone of amaturely karstified aquifer, Mendip Hills, 
England, Proceedings of the Conference on Environ-mental Problems in Karst Terrains and Teir Solution, Bowling Green, Kentucky, National Water Well Association, 57-87, 1987.

Spötl, C., Fairchild, I. J., and Tooth, A. F.: Cave air control on dripwater geochemistry, Obir Caves (Austria): Implications for speleothem deposition in dynamically ventilated caves, Geochim. Cosmochim. Ac., 69, 2451-2468, 2005.

Spötl, C. and Mattey, D.: Stable isotope microsampling of speleothems for palaeoenvironmental studies: A comparison of microdrill, micromill and laser ablation techniques, Chem. Geol., 235, 48-58, 2006.

Tarutani, T., Clayton, R. N., and Mayeda, T. K.: Effect of polymorphism and magnesium substitution on oxygen isotope fractionnation between calcium carbonate and water, Geochim. Cosmochim. Ac., 33, 987-996, 1969.

Thornthwaite, C.: An approaxh toward a rational classification of climate, Geographical Review, 38, 55-94, 1948.

Treble, P., Shelley, J. M. G., and Chappell, J.: Comparison of high resolution sub-annual records of trace elements in a modern (1911-1992) speleothem with instrumental climate data from southwest Australia, Earth Planet. Sci. Lett., 216, 141-153, 2003.

Tremaine, D. M., Froelich, P. N., and Wang, Y.: Speleothem calcite farmed in situ: Modern calibration of delta $\delta^{18} \mathrm{O}$ and $\delta^{13} \mathrm{C}$ paleoclimate proxies in a continuously-monitored natural cave system, Geochim. Cosmochim. Ac., 75, 4929-4950, 2011.

Van Rampelbergh, M., Fleitmann, D., Verheyden, S., Cheng, H., Edwards, L., De Geest, P., De Vleeschouwer, D., Burns, S. J., Matter, A., Claeys, P., and Keppens, E.: Mid- to late Holocene Indian Ocean Monsoon variability recorded in four speleothems from Socotra Island, Yemen, Quat. Sci. Rev., 65, 129-142, 2013.
Verheyden, S.: Speleothems as palaeoclimatic archives, Isotopic and geochemical study of the cave environment and its Late Quaternary records, Unpubl. PhD Thesis, Vrije Universiteit Brussel, Belgium, 132 p., 2001.

Verheyden, S., Baele, J.-M., Keppens, E., Genty, D., Cattani, O., Hai, C., Edwards, L., Hucai, Z., Van Strijdonck, M., and Quinif, Y:: The proserpine stalagmite (Han-sur-Lesse cave, Belgium): preliminary environmental interpretation of the last 1000 years as recorded in a layered speleothem, Geol. Belg., 9, 245-256, 2006.

Verheyden, S., Genty, D., Deflandre, G., Quinif, Y., and Keppens, E.: Monitoring climatological, hydrological and geochemical parameters in the Pere Noel cave (Belgium): implication for the interpretation of speleothem isotopic and geochemical timeseries, Int. J. Speleol., 37, 221-234, 2008a.

Verheyden, S., Nader, F. H., Cheng, H. J., Edwards, L. R., and Swennen, R.: Paleoclimate reconstruction in the Levant region from the geochemistry of a Holocene stalagmite from the Jeita cave, Lebanon, Quaternary Res., 70, 368-381, 2008 b.

Wang, Y., Cheng, H., Edwards, R. L., Kong, X., Shao, X., Chen, S., Wu, J., Jiang, X., Wang, X., and An, Z.: Millennial- and orbital-scale changes in the East Asian monsoon over the past 224000 years, Nature, 451, 1090-1093, 2008. 